\title{
Current perspectives on therapeutic ultrasound in the management of chronic wounds: a review of evidence
}

This article was published in the following Dove Press journal:

Chronic Wound Care Management and Research

26 July 2017

Number of times this article has been viewed

\author{
Teresa Conner-Kerr' \\ Mary Ellen Oesterle ${ }^{2}$ \\ 'College of Health Sciences \& \\ Professions, ${ }^{2}$ Department of Physical \\ Therapy, University of North Georgia, \\ Dahlonega, GA, USA
}

\begin{abstract}
Although therapeutic ultrasound has been in existence since the 1930s, questions remain as to its effectiveness in promoting tissue healing in various injured tissues. These tissues include soft tissues such as skin, tendons, ligaments, bursae, joint capsules and muscles. Limited evidence exists to support a role for therapeutic ultrasound in closed, soft tissue lesions. However, an evolving literature provides support for the role of therapeutic ultrasound in the treatment of chronic wounds, acute injuries such as fractures and split thickness graft donor sites as well as in the modulation of wound-related pain. Modern technology that uses low-frequency (kilohertz), long wave ultrasound appears promising compared to older, higher frequency ultrasound (megahertz) devices. These newer devices appear to have positive effects on healing rates in various wound types, pain levels and the modulation of proinflammatory cytokines.
\end{abstract}

Keywords: low-frequency ultrasound, non-contact ultrasound, $\mathrm{KHz}$, acoustic, healing, cavitation

\section{Introduction}

Therapeutic ultrasound has been used extensively to promote tissue healing for over 60 years. ${ }^{1,2}$ Harvey $^{3}$ in 1930 published an article on the physical, chemical and biological effects of ultrasound. He noted that ultrasound induces changes in biological tissues including alterations in macromolecules, microbes, cells, tissues and organs. Early on it was recognized that ultrasound could be used to heat biological tissues, and published evidence indicates that ultrasound was used therapeutically to heat tissues in the $1930 \mathrm{~s} .{ }^{4}$ Because of this application, ultrasound is widely used as a physical therapeutic agent in the 1930s and $1940 \mathrm{~s}^{5}$ and continues to be used today in modern rehabilitation. ${ }^{6}$ In fact, a survey published in 2007 examining the contemporary use of therapeutic ultrasound by physical therapists who are orthopedic certified specialists found that therapeutic ultrasound is widely used to treat soft tissue inflammation, tissue restrictions, scars, pain and edema.

\section{Thermal and nonthermal effects of therapeutic ultrasound}

Therapeutic ultrasound is inaudible, high-frequency $(>20,000 \mathrm{kHz})^{7}$ mechanical vibrations that are produced when electrical energy is transformed into acoustic energy. Therapeutic ultrasound encompasses a frequency range from $20 \mathrm{kHz}$ to $3 \mathrm{MHz}$. $\mathrm{High}$ frequency therapeutic ultrasound $(>20,000 \mathrm{kHz})$ produces a number of biological effects through primarily two mechanisms, thermal and nonthermal effects. ${ }^{2,8}$ Therapeutic ultrasound delivered by continuous wave $(100 \%$ duty cycle; continuous delivery of
Correspondence: Teresa Conner-Kerr College of Health Sciences \& Professions, University of North Georgia, 319 A HNS Building, Dahlonega, GA 30597, USA Tel +l 7068674507

Email teresa.conner-kerr@ung.edu 
acoustic energy) application at higher intensities can produce time- and dose-dependent increases in tissue temperature. ${ }^{9-12}$ Acoustic energy is absorbed by biological tissues especially those high in collagen and other protein containing fibers, and this energy is converted to heat energy. Resultant tissue heating leads to increased blood flow and tissue extensibility culminating in enhanced healing and mobility.

In comparison, the nonthermal effects of ultrasound are related to acoustic streaming and cavitation. ${ }^{2,7,8}$ Acoustic streaming is the unidirectional movement of fluid along cell membranes as a result of the ultrasound or mechanical pressure wave pushing fluid past these structures. ${ }^{8}$ In comparison, cavitation occurs when the mechanical pressure waves compress and subsequently decompress microscopic gas bubbles located within biological fluid. The propagation of sound (mechanical pressure) waves through biological tissues produces a rolling cycle of compression and rarefaction of the exposed tissue. This compression and rarefaction of exposed tissue causes the microscopic gas bubbles to contract and expand. ${ }^{1,2,7,8}$ The rapid oscillation of gas bubbles may result in cell damage when these gas bubbles expand quickly and then collapse. This violent collapse has been likened to a micro explosion and is termed unstable cavitation. Unstable cavitation may disrupt cellular membranes, thus altering the function of the cell. However, this form of cavitation is not thought to occur with therapeutic ultrasound treatments.

A number of biological effects have been attributed to the induction of acoustic streaming and cavitation in tissues exposed to therapeutic ultrasound. In vitro studies have demonstrated growth retardation of cells ${ }^{13}$ that are exposed to therapeutic ultrasound along with increased protein synthesis $^{14,15}$ and cell membrane alterations. ${ }^{16,17}$ These cellular effects are seen with both continuous and pulsed ultrasound at therapeutic levels ranging from 0.1 to $1.7 \mathrm{~W} / \mathrm{cm}^{2} .{ }^{13-15,18}$

\section{Biological effects of therapeutic ultrasound}

Various biological effects associated with therapeutic ultrasound have been detected in vitro and in vivo. ${ }^{19}$ Most of these studies used 1-3 $\mathrm{MHz}$ frequencies and intensities between 0.1 and $1.5 \mathrm{~W} / \mathrm{cm}^{2} .^{20-26}$ Therapeutic ultrasound altered cell membrane properties including cellular adhesion, ${ }^{20}$ membrane permeability, ${ }^{21}$ calcium ion flux, ${ }^{21}$ biological protein levels ${ }^{22}$ and proliferative processes. ${ }^{23}$ Nonthermal therapeutic ultrasound exposure increased intracellular calcium levels, ${ }^{21}$ fibroblast proliferation, ${ }^{24}$ collagen production ${ }^{25}$ and fibroblast migration patterns. ${ }^{26}$ These biological effects are consistent with the theory that therapeutic ultrasound applied using nonthermal parameters may enhance the function of fibroblasts leading to increased collagen synthesis and matrix repair.

Similarly, the enhanced proliferation rates of different wound bed cells exposed to the above described frequencies and intensities also speaks to the potential for therapeutic ultrasound delivered at nonthermal parameters to enhance tissue healing. ${ }^{23}$ Therapeutic ultrasound delivered at nonthermal parameters has been shown to increase proliferation specifically of T-cells, osteoblasts and fibroblasts. Furthermore, protein factors that stimulate a range of cellular responses were also elevated with the application of nonthermal ultrasound. ${ }^{22}$ Increases in interleukin 8 (IL-8) by osteoblasts, vascular endothelial growth factor (VEGF) by osteoblasts and monocytes, basic fibroblast growth factor by osteoblasts stimulate endothelial cell migration and proliferation, all functions are required for new blood vessel formation and tissue healing (refer Table 1 for overview of biological proteins and functions). Studies using the use of kiloHertz frequencies $(35,40$ and $45 \mathrm{kHz})$ with treatment intensities between 5 and $100 \mathrm{~mW} / \mathrm{cm}^{2}$ have been linked to increased production of IL-1 and IL-8, VEGF, fibroblast growth factor $\beta$, collagen production and specific patterns of fibroblast migration. ${ }^{19}$

However, many of these effects have not been confirmed in humans. A recent study by Yao et $\mathrm{al}^{27}$ demonstrated a modulatory effect of $40 \mathrm{kHz}$ ultrasound on proinflammatory cytokines, matrix enzymes and VEGF. Low-frequency ultrasound (LFU) using a $40 \mathrm{kHz}$ generator resulted in a trend toward the reduction of proinflammatory cytokines (IL-6, IL-8, IL-1 $\beta$, tumor necrosis factor-alpha [TNF- $\alpha]$

Table I Biological effects associated with nonthermal therapeutic ultrasound induced increases in cellular protein production

\begin{tabular}{llll}
\hline $\begin{array}{l}\text { Increases in protein } \\
\text { production }\end{array}$ & Biological effect & Functional effect & $\begin{array}{l}\text { Treatment frequency } \\
\text { used in experiment }\end{array}$ \\
\hline Interleukins $8^{19}$ & Endothelial cell migration and proliferation & Formation of new blood vessels in tissue healing & $\mathrm{MHz} ; \mathrm{kHz}$ \\
VEGF $^{19}$ & Endothelial cell migration and proliferation & Formation of new blood vessels in tissue healing & $\mathrm{MHz} ; \mathrm{kHz}$ \\
FGF $^{19}$ & Fibroblast growth & Collagen formation for matrix production & $\mathrm{MHz} ; \mathrm{kHz}$ \\
Collagen $^{19,25}$ & Tissue matrix formation & Tissue healing & $\mathrm{MHz} \mathrm{kHz}$ \\
\hline
\end{tabular}

Abbreviation: VEGF, vascular endothelial growth factor; FGF $\beta$, fibroblast growth factor beta. 
and granulocyte macrophage colonystimulating [GM-CSF]) matrix metalloproteinases, VEGF and macrophage number with noncontact, low-frequency ultrasound (NCLFU).

\section{Therapeutic ultrasound and accepted practice}

The use of therapeutic ultrasound continues today by not only physical therapists but also physicians, podiatrists, chiropractors, nurses and occupational therapists. These practitioners use therapeutic ultrasound to treat a wide range of tissues including skin, tendon, ligament, joint capsule, bursa, muscle and bone. However, questions remain as to the effectiveness of therapeutic ultrasound in the treatment of these tissue injuries. These questions in large part are due to lack of well-designed controlled studies with large participant numbers, standardized treatment approaches and verification of in vitro and in vivo effects occurring in humans treated with therapeutic ultrasound. ${ }^{19}$

\section{Therapeutic ultrasound treatment of closed soft tissue injuries}

While the focus of this article is not on the effects of therapeutic ultrasound on closed soft tissue injuries, it is interesting to review the results of these studies because similar megaHertz generating acoustic devices are used along with treatment parameters (contact ultrasound application, megaHertz frequencies $[1-3 \mathrm{MHz}]$ and pulsed, low-intensity ultrasound often used in treating chronic open wounds). One notable difference that must be taken into account is that, unlike the open chronic wound studies, debridement is not paired with the treatment due to the closed nature of the injury. As a result, the injured tissue does not receive a "jump start" or conversion to an acute wound like a chronic open wound that is being actively debrided.

Similarly, review of this literature brings a helpful perspective because similarly injured tissues such as connective tissue, tendons, ligaments, joint capsules and muscle are involved in both open and closed wounds. The rest of this article will specifically delve into the literature surrounding the use of both high-frequency ultrasound (HFU, MHz) and LFU $(\mathrm{kHz})$ for the treatment of open, chronic wounds. However, the effects of therapeutic ultrasound on injured soft tissue are reviewed briefly subsequently.

A recent study published by Chinn et $\mathrm{al}^{28}$ concluded that the current evidence for the use of therapeutic ultrasound in the treatment of soft tissue injury is low. Chinn et $\mathrm{al}^{28}$ located seven good quality studies using PubMed and Cochrane databases. Of these seven studies, only two demonstrated any clinical benefit of the treatment of injured soft tissue with therapeutic ultrasound. These findings are consistent with those reported by Shanks et al, ${ }^{29}$ Robertson and Baker, ${ }^{30}$ Van der Windt et $\mathrm{al}^{31}$ and Gam and Johannsen. ${ }^{32}$ They concluded that the evidence did not support the use of therapeutic ultrasound in the treatment of soft tissue injuries.

Similarly, there is some low-level evidence that indicates that therapeutic ultrasound benefits fresh fracture healing. In a recent network meta-analysis, Ebrahim et a ${ }^{33}$ examined the effect of low intensity pulsed ultrasound (LIPUS) versus electrical stimulation on fresh fractures, delayed union fractures or nonunion fractures. Two independent reviewers performed the assessment of 15 trials. The investigators concluded that poor-quality evidence indicated that patients with fresh fractures who were treated with LIPUS demonstrated a clinical benefit at 6 months. An earlier meta-analysis performed by Busse et a ${ }^{34}$ revealed moderate- to low-quality evidence for LIPUS in healing fractures.

The benefits detected in patients with fresh fractures who were treated with therapeutic ultrasound may be related to the effects of therapeutic ultrasound on acute tissue injuries. In the author's experience with NCLFU dating back to original unpublished studies (Conner-Kerr et al, ${ }^{35}$ presented in 2003 at the Symposium on Advanced Wound Care) performed using the initial prototype for the $\mathrm{MIST}^{\circledR}$ therapy device, infected, acute porcine wounds healed $30 \%$ faster than control, infected wounds. A prospective, randomized controlled trial conducted by Prather et $\mathrm{al}^{36}$ examining the effects of $40 \mathrm{kHz}$ NCLFU plus standard of care (SOC) therapy versus SOC therapy revealed significantly faster rates of healing in patients with split thickness donor sites. The mean time to healing was 12.1 days in the NCLFU plus SOC versus 21.3 days in the SOC therapy-only group. One hundred percent of the NCLFU plus SOC therapy group epithelialized in 4 weeks compared to $71 \%$ in the SOC-only treatment group. The NCLFU plus SOC therapy group experience less itching and pain as well as decreased recidivism rate of $8 \%$ versus $45 \%$ for the SOC therapy-only group. This increased rate of re-epithelialization is similar to the $30 \%$ increased rate of healing observed in our acute porcine wound model referenced earlier and may demonstrate the maximum biological shift in healing rates that can be achieved with NCLFU treatment of acute wounds. Acute wounds may be more responsive to therapeutic ultrasound treatment and this may account for the increased healing rates observed also in individuals with fresh fractures. 


\section{Reimbursement status of therapeutic ultrasound for open chronic wounds}

Even after more than 80 years of study, ${ }^{1}$ there remains a lack of consensus in the scientific community as to the mechanism of action by which ultrasound affects biological tissues and its effectiveness in treating human tissues. Health care providers and the insurance industry continue to question the effectiveness of this therapy in treating chronic open wounds. For example, the clinical policy bulletin (\#0372) for Aetna ${ }^{\circledR}$ dated August 16, 2016 (last review date; next review date April 13, 2017; effective date February 7, 2000) states "Aetna considers noncontact, non-thermal, low-frequency ultrasound therapy experimental and investigational for the treatment of wounds because its effectiveness has not been established" (accessed February 12, 2017, 2016). Similarly, the United HealthCare Services, Inc. commercial medical policy effective October 1, 2016, states in their coverage rational,
"Low frequency ultrasound is unproven and not medically necessary for treating wounds" (accessed February 16, 2017, 2016). Additionally, United HealthCare Services, Inc. does state in their commercial medical policy that "Medicare does not have a National Coverage Determination (NCD) for LFU for the treatment of wounds. Local Coverage Determinations (LCDs) exist; see the LCDs for Non-covered Services and Wound Care" (accessed February 16, 2017, 2016). Comparison of the national coverage policy for three of the top five commercial health care plans is shown in Table 2.

\section{Critical literature reviews assessing the effectiveness of therapeutic ultrasound}

Because of the questions that remain about the effectiveness of therapeutic ultrasound on tissue healing, various critical literature reviews (narrative or traditional reviews, metaanalysis, and systematic reviews) have been conducted over

Table 2 National coverage decision of health plans in the top five by market share (according to NAIC)

\begin{tabular}{|c|c|c|c|c|c|}
\hline $\begin{array}{l}\text { Corporate } \\
\text { medical policy }\end{array}$ & Website location & Policy statement & $\begin{array}{l}\text { Policy } \\
\text { number }\end{array}$ & $\begin{array}{l}\text { Last CAP } \\
\text { review }\end{array}$ & $\begin{array}{l}\text { Next CAP } \\
\text { review }\end{array}$ \\
\hline $\begin{array}{l}\text { United Health } \\
\text { Care }^{\circledR}\end{array}$ & $\begin{array}{l}\text { https://www.unitedhealthcareonline.com/ } \\
\text { ccmcontent/ProviderlI/UHC/en-US/Main\%20Menu/ } \\
\text { Tools\%20\&\%20Resources/Policies\%20and\%20 } \\
\text { Protocols/Medicare\%20Advantage\%20Policy\%20 } \\
\text { Guidelines/Low_Frequency_NC_NT_Ultrasound. } \\
\text { pdf }\end{array}$ & $\begin{array}{l}\text { Use of low-frequency, } \\
\text { noncontact, } \\
\text { nonthermal, } \\
\text { ultrasound therapy } \\
\text { is considered } \\
\text { investigational and not } \\
\text { medically necessary } \\
\text { for all applications. }\end{array}$ & $\begin{array}{l}2016 \mathrm{TO} \\
521 \mathrm{~K}\end{array}$ & $10 / 16$ & Not stated \\
\hline Anthem $^{\circledR}$ & $\begin{array}{l}\text { https://www.anthem.com/medicalpolicies/policies/ } \\
\text { mp_pw_a070642.htm }\end{array}$ & & MED 00096 & $11 / 16$ & Not stated \\
\hline Aetna $^{\circledR}$ & $\begin{array}{l}\text { http://www.aetna.com/cpb/medical/ } \\
\text { data/700_799/0746.html }\end{array}$ & $\begin{array}{l}\text { Aetna considers } \\
\text { ultrasound therapy } \\
\text { (including high- } \\
\text { frequency ultrasound, } \\
\text { noncontact low- } \\
\text { frequency ultrasound } \\
\text { devices) for wound } \\
\text { healing and reduction } \\
\text { of chronic wound } \\
\text { pain experimental and } \\
\text { investigational because } \\
\text { its effectiveness for } \\
\text { these indications has } \\
\text { not been established. }\end{array}$ & 0746 & $10 / 16$ & $8 / 17$ \\
\hline Medicare & $\begin{array}{l}\text { https://www.unitedhealthcareonline.com/ } \\
\text { ccmcontent/ProviderlI/UHC/en-US/Main\%20Menu/ } \\
\text { Tools\%20\&\%20Resources/Policies\%20and\%20 } \\
\text { Protocols/Medicare\%20Advantage\%20Policy\%20 } \\
\text { Guidelines/Low_Frequency_NC_NT_Ultrasound. } \\
\text { pdf }\end{array}$ & $\begin{array}{l}\text { Does not have a } \\
\text { national coverage } \\
\text { determination; } \\
\text { local coverage } \\
\text { determinations exist }\end{array}$ & NA & NA & NA \\
\hline
\end{tabular}

Note: Data from Dark Daily: Serving Clinical Labs \& Pathology Groups. ${ }^{60}$

Abbreviations: CAP, Consultant Advisory Panel; NAIC, National Association of Insurance Commissioners; NA, not applicable. 
the years (refer Table 3 for an overview of study outcomes). Between 1998 and 2016, there have been some seven highlevel critical reviews (meta-analysis, systematic reviews) of the literature examining specifically the effects of therapeutic ultrasound on chronic wound healing. ${ }^{37-43}$

Of these studies, three studies found no evidence of benefit for therapeutic ultrasound treatment of pressure ulcers ${ }^{38,40,41}$ and one study found unknown effectiveness of therapeutic ultrasound in the treatment of pressure and venous ulcers. ${ }^{39}$ One study found evidence that ultrasound treatment of the periwound tissue that surrounds the wound bed produced beneficial effects on healing. ${ }^{37}$ Two other studies found evidence to support the use of therapeutic ultrasound. ${ }^{42,43}$ One study detected increased healing at 7-8 weeks with $\mathrm{HFU},{ }^{42}$ and another demonstrated that NCLFU produced consistent and substantial wound healing as well as enhanced rates of healing. ${ }^{43}$

An early review of the literature by Johannsen et $\mathrm{al}^{37}$ reported that therapeutic ultrasound was most effective when delivered in low doses to the periwound or wound edge. A Cochrane review of the literature in $2006^{38}$ concluded that the evidence did not support a role for ultrasound in the treatment of pressure ulcers. It was further noted that the small number of participants, methodological flaws and small number of trials prohibited the determination of any beneficial or harmful effects of ultrasound treatments on pressure ulcers.

Systematic reviews by Nelson and Jones ${ }^{39}$ further indicated that the effects of therapeutic ultrasound on pressure and venous ulcers are unknown. In $2008,{ }^{44}$ a systematic review by Hinchliffe et al concluded that no evidence was found to support the use of "more expensive treatments" in the clinical management of chronic diabetic foot wounds. Sixty studies were examined in the review, and ultrasound was listed as one of the product categories examined for potential effectiveness in healing diabetic foot ulcers (DFUs). Similarly, Reddy et $\mathrm{al}^{40}$ in a systematic review of randomized controlled trials found little evidence to support the use of ultrasound in treating pressure ulcers.

A subsequent Cochrane review in $2010^{42}$ examined the effectiveness of ultrasound on healing venous leg ulcers. Eight randomized controlled trials were examined by two authors independently. All of these studies had unclear or high risk of bias and used different durations of follow-up and treatment durations with ultrasound. Six trials evaluated HFU and two trials evaluated LFU. With the HFU studies, five demonstrated significantly higher healing at 7-8 weeks, whereas no difference was detected with the two LFU trials.

Gottrup and Apelqvist ${ }^{45}$ examined the evidence to support the use of traditionally accepted and new therapeutic devices to encourage healing of DFU. The effectiveness of ultrasound therapy was analyzed along with other treatment modalities. The review found a paucity of high-quality evidence due to a number of factors. These factors included inadequate sample size and controls, short follow-up, lack of randomization, nonblinded assessment of outcomes, to name a few. In 2013, Kwan et $\mathrm{al}^{46}$ further assessed the effectiveness of physical therapeutic modalities in DFU healing. Only randomized controlled trials located in MEDLINE, CINAHL, EMBASE and the Cochrane Central Register of Controlled Trials from 1966 to 2011 were used for the analysis. Eight randomized controlled trials were assessed. Only one study examined the effects of therapeutic ultrasound on DFUs. While the study indicated a positive effect of ultrasound treatment compared to control, the small treatment group numbers did not provide definitive evidence to rule out harmful effects of ultrasound.

Table 3 Effects of ultrasound on chronic wounds: critical review of the literature

\begin{tabular}{|c|c|c|c|c|}
\hline Author & $\begin{array}{l}\text { Year } \\
\text { published }\end{array}$ & Type of review & Type of wound & Finding \\
\hline Johannsen et $\mathrm{a}^{37}$ & 1998 & Meta-analysis & Chronic leg ulcers & Ultrasound treatment has best effect when applied to periwound \\
\hline Baba-Akbari ${ }^{38}$ & 2006 & $\begin{array}{l}\text { Systematic review } \\
\text { (Cochrane review) }\end{array}$ & Pressure ulcers & No evidence of benefit \\
\hline Nelson and Jones ${ }^{39}$ & 2007 & Systematic review & $\begin{array}{l}\text { Pressure ulcers } \\
\text { Venous ulcers }\end{array}$ & Unknown effectiveness \\
\hline Reddy et $\mathrm{al}^{40}$ & 2008 & Systematic review & Pressure ulcers & No clear evidence to support \\
\hline $\begin{array}{l}\text { Ontario Ministry of } \\
\text { Health and Long Term } \\
\text { Care }^{4 l}\end{array}$ & 2009 & $\begin{array}{l}\text { Evidence-based } \\
\text { analysis }\end{array}$ & Pressure ulcers & No evidence of benefit \\
\hline Cullum et $\mathrm{al}^{42}$ & 2010 & $\begin{array}{l}\text { Systematic review } \\
\text { (Cochrane review) }\end{array}$ & Venous ulcers & $\begin{array}{l}\text { No reliable evidence of benefit; significantly more patients healed } \\
\text { with HFU in } 5 \text { of } 6 \text { independent small trials at } 7-8 \text { weeks }\end{array}$ \\
\hline Driver et $\mathrm{al}^{43}$ & 2011 & Meta-analysis & Chronic wounds & $\begin{array}{l}\text { NCLFU resulted in consistent and substantial wound size } \\
\text { reduction and favorable healing rates }\end{array}$ \\
\hline
\end{tabular}

Abbreviations: HFU, high-frequency ultrasound; NCLFU, noncontact, low-frequency ultrasound. 
In 2011, Driver et $\mathrm{al}^{43}$ conducted a meta-analysis to determine the effects of NCLFU on chronic wound healing. Eight published studies (one randomized, double-blind, sham-controlled study, five retrospective studies and two prospective nonrandomized studies) with 444 participants were examined. The effects of NCLFU on wound size including volume reduction and rate of healing were studied. Analysis of four of these studies with a total of 188 patients revealed that wound area decreased by approximately $85 \%$ over a 7-week period. Wound volume was also reduced in a similar fashion $(\sim 80 \%)$ in four studies with 278 individuals over a 12-week period with NCLFU treatment. Analysis of seven studies (429 participants) demonstrated that $32.7 \%$ of wounds healed by 6 weeks and $41.7 \%$ of wounds healed by 12 weeks when treated with NCLFU. The mean time to healing in individuals treated with NCLFU was 8.2 weeks. Overall, the study authors concluded that NCLFU reduced wound size including volume and enhanced healing rates in persons with chronic wounds.

\section{Original studies of the effectiveness of therapeutic ultrasound}

Eleven studies were included in this review section (refer Table 4 for an overview) ${ }^{47-57}$ Six of the studies were randomized controlled trials, ${ }^{47,50,52,54,55,57}$ two studies were placebocontrolled (mock intervention used) trials, ${ }^{48,49}$ one study was a retrospective analysis/case series,$^{53}$ one study was a comparative analysis ${ }^{54}$ and one study was a non-comparative analysis. ${ }^{51}$ Four studies examined venous ulcers, ${ }^{49,55-57}$ five studies examined chronic leg ulcers ${ }^{47,48,51,53}$ with one study that included individuals that also had critical limb ischemia, ${ }^{52}$ one study examined DFUs ${ }^{50}$ and one study examined pressure ulcers. ${ }^{54}$ Only two studies ${ }^{47,48}$ reported no significant differences in any measured dependent variable.

Table 4 Effects of ultrasound on wound healing in original studies

\begin{tabular}{|c|c|c|c|c|c|}
\hline Author & Year & Type of study & $\begin{array}{l}\text { Ultrasound } \\
\text { frequency and } \\
\text { intensity }\end{array}$ & Type of wound & Outcome \\
\hline Lundeberg et $\mathrm{a}^{47}$ & 1990 & $\mathrm{RCT}$ & $\mathrm{I} \mathrm{MHz} ; 0.5 \mathrm{~W} / \mathrm{cm}^{2}$ & Chronic leg ulcers & $\begin{array}{l}\text { No significant differences between pulsed } \\
\text { ultrasound and conventional care and conventional } \\
\text { care alone. }\end{array}$ \\
\hline Eriksson et al ${ }^{48}$ & 1991 & $\begin{array}{l}\text { Placebo-controlled } \\
\text { trial }\end{array}$ & I MHz; I W/cm² & Chronic leg ulcers & $\begin{array}{l}\text { No significant difference between ultrasound and } \\
\text { placebo group. }\end{array}$ \\
\hline Peschen et $\mathrm{a}^{49}$ & 1997 & $\begin{array}{l}\text { Placebo-controlled } \\
\text { trial }\end{array}$ & $\begin{array}{l}30 \mathrm{kHz} ; 100 \mathrm{~mW} / \mathrm{cm}^{2} \\
\text { Waterbath }\end{array}$ & Venous ulcers & $\begin{array}{l}\text { Ultrasound plus conventional therapy group } \\
\text { exhibited a significantly greater decrease in wound } \\
\text { area compared to conventional treatment group }\end{array}$ \\
\hline Ennis et $\mathrm{a}^{50}$ & 2005 & $\begin{array}{l}\text { Double-blind, } \\
\text { multicenter RCT }\end{array}$ & $40 \mathrm{kHz} ;$ noncontact & $\begin{array}{l}\text { Diabetic foot } \\
\text { ulcers }\end{array}$ & $\begin{array}{l}\text { Ultrasound plus SOC significantly increased healing } \\
\text { compared to SOC }\end{array}$ \\
\hline Ennis et $\mathrm{a}^{51}$ & 2006 & $\begin{array}{l}\text { Noncomparative } \\
\text { study }\end{array}$ & $40 \mathrm{kHz}$; noncontact & $\begin{array}{l}\text { Chronic lower } \\
\text { extremity wounds }\end{array}$ & $\begin{array}{l}\text { Ultrasound-treated wounds achieved healing more } \\
\text { rapidly than historic controls }\end{array}$ \\
\hline Kavros et al ${ }^{52}$ & 2007 & Prospective, RCT & $40 \mathrm{kHz}$; noncontact & $\begin{array}{l}\text { Leg and foot } \\
\text { ulcers; critical limb } \\
\text { ischemia }\end{array}$ & $\begin{array}{l}\text { Significantly greater number of individuals treated } \\
\text { with ultrasound plus SOC achieved greater than } \\
50 \% \text { wound healing at } 12 \text { weeks compared to SOC } \\
\text { alone. }\end{array}$ \\
\hline $\begin{array}{l}\text { Kavros and } \\
\text { Schenck }\end{array}$ & 2008 & $\begin{array}{l}\text { Retrospective } \\
\text { analysis; } \\
\text { nonrandomized, } \\
\text { baseline-controlled } \\
\text { clinical case series }\end{array}$ & $40 \mathrm{kHz}$; noncontact & $\begin{array}{l}\text { Chronic leg and } \\
\text { foot ulcers }\end{array}$ & $\begin{array}{l}\text { Wound volume and weeks to healing were } \\
\text { significantly reduced in the ultrasound-treated } \\
\text { group. }\end{array}$ \\
\hline Polak et a ${ }^{54}$ & 2014 & Prospective, RCT & $\mathrm{I} \mathrm{MHz} ; 0.5 \mathrm{~W} / \mathrm{cm}^{2}$ & $\begin{array}{l}\text { Stage II and III } \\
\text { pressure ulcers }\end{array}$ & $\begin{array}{l}\text { Wound surface area was significantly reduced with } \\
\text { the HFU group at } 6 \text { weeks. }\end{array}$ \\
\hline Olyaie et $\mathrm{al}^{55}$ & 2013 & RCT & $40 \mathrm{kHz}$; noncontact & Venous ulcers & $\begin{array}{l}\text { Significant reduction in pain and edema scores in } \\
\text { ultrasound-treated group. }\end{array}$ \\
\hline Beheshti et $\mathrm{al}^{56}$ & 2014 & Comparative study & $\begin{array}{l}\text { HFU; } \\
40 \mathrm{kHz} \text { noncontact }\end{array}$ & Venous ulcers & $\begin{array}{l}\text { Size of ulcer, mean degree of pain and edema } \\
\text { were significantly decreased in ultrasound group } \\
\text { compared to standard treatment group. }\end{array}$ \\
\hline White et $\mathrm{al}^{57}$ & 2015 & $\begin{array}{l}\text { RCT; single center, } \\
\text { blinded }\end{array}$ & $40 \mathrm{kHz}$; noncontact & Venous ulcers & $\begin{array}{l}\text { Substantial mean reduction in pain in the ultrasound } \\
\text { plus SOC group; Non significant changes in wound } \\
\text { area, infections and QoL. }\end{array}$ \\
\hline
\end{tabular}

Abbreviations: RCT, randomized controlled trial; SOC, standard of care; HFU, high-frequency ultrasound; QoL, quality of life. 
The effects of pulsed ultrasound in the treatment of chronic leg ulcers was examined by Lundeberg et $\mathrm{al}^{47}$ in a randomized controlled trial involving 44 patients. Pulsed ultrasound plus SOC therapy was compared to SOC therapy plus placebo-ultrasound.

Patients were treated 3 times per week using pulsed ultrasound delivered with a $1 \mathrm{MHz}$ frequency generator. No significant differences were detected between the treatment groups at 4,8 and 12 weeks. Eriksson et al ${ }^{48}$ conducted another randomized controlled trial in 1991.

A similar paradigm was followed with patients receiving ultrasound plus SOC therapy or SOC therapy plus placeboultrasound. Ultrasound therapy was delivered continuously for 10 minutes at thermal parameters $\left(1 \mathrm{~W} / \mathrm{cm}^{2}\right)$ using a $1 \mathrm{MHz}$ generator. Similarly, no significant difference in wound area or rate of healing was detected at 2, 4, 6 and 8 weeks.

In contrast, a 1997 placebo-controlled, single-blinded, clinical study by Peschen et $\mathrm{al}^{49}$ discovered that lowfrequency and low-dose ultrasound facilitates healing in chronic venous ulcers. The effects of low-frequency (30 kHz), low-dose ultrasound was examined in 24 patients randomly assigned to conventional therapy versus LFU plus conventional therapy for 12 weeks. Continuous ultrasound at $100 \mathrm{~mW} / \mathrm{cm}^{2}$ was applied 3 times per week. Wounds were measured using planimetry at baseline, 2, 4, 6, 8, 10 and 12 weeks of therapy. The LFU plus conventional therapy group exhibited a $55.4 \%$ decrease in wound area compared to $16.5 \%$ for the conventional therapy-only group.

In 2004, a new device was approved by the FDA that allowed ultrasound to be transmitted on a saline particle mist to the wound bed (www.aetna.com/cpb/medical/data). The frequency generator produced a $40 \mathrm{kHz}$ frequency as opposed to commonly used ultrasound devices that had $\mathrm{MHz}$ generators that required a contact application procedure.

Ennis et $a l^{50}$ studied the effects of this NCLFU on diabetic ulcers in a randomized, double-blinded, controlled, multicenter trial in a 2005 study. Fifty-five patients received either SOC therapy and the NCLFU device or SOC therapy plus a sham device. After 12 weeks, $40.7 \%$ of DFUs healed versus $14.3 \%$ in the SOC and sham therapy group. In a second study, Ennis et al ${ }^{51}$ examined the incidence of wound closure for chronic, nonhealing lower extremity wounds treated with the NCLFU device. Median time to healing with the NCLFU as a stand-alone therapy was 7 weeks compared to 10 weeks for historic controls.

In 2007, Kavros et al ${ }^{12}$ conducted a prospective, randomized, controlled study examining the effectiveness of NCLFU in individuals with nonhealing leg and foot ulcer who had critical limb ischemia. Patients received either NCLFU plus SOC or SOC alone 3 times per week for 12 weeks or until healed. Patients receiving NCLFU plus SOC healed by a significantly higher percentage (63\%) than SOC alone (29\%). Kavros and Schenck ${ }^{53}$ performed an open-label, nonrandomized, baseline-controlled clinical case series investigating the effect of NCLFU on healing chronic, recalcitrant lower extremity wounds. The mean time in treatment was 5.5 weeks for NCLFU plus SOC compared to 9.8 weeks for SOC alone. Percentage of wound volume reductions is $37 \%$ in the SOC group versus $95 \%$ in the NCLFU plus SOC group.

Polak et al ${ }^{54}$ studied specifically the effectiveness of HFU (MHz ultrasound) on pressure ulcer healing. In a prospective randomized, controlled trial, he examined the effects of HFU on Stage II and III pressure ulcers. Study participants were assigned randomly to either a control group that received SOC therapy only or a treatment group that received SOC therapy along with HFU. HFU was delivered at $1 \mathrm{MHz}$, $0.5 \mathrm{~W} / \mathrm{cm}^{2}$ at a $20 \%$ duty cycle for $1-3 \mathrm{~min} / \mathrm{cm}^{2}$ in 1 session per day $/ 5$ days per week for 6 weeks or until wound closure. The wound surface area (WSA) decreased significantly after 6 weeks with a significantly greater reduction in the SOC-HFU ( $\sim 69 \% \pm 37.23 \%)$-treated group compared to the SOC $(37.24 \% \pm 57.84 \% ; p<0.05)$ therapy-only group. The mean weekly reduction in WSA was greater for the SOCHFU group compared to the SOC therapy-only group. A higher percentage Stage II pressure ulcers decreased in size by $50 \%$ in the SOC-HFU-treated group compared to SOC therapy alone.

In 2013, Olyaie et $\mathrm{al}^{55}$ in a small randomized, controlled trial examined the effectiveness of either HFU or NCLFU and SOC therapy or SOC therapy alone on venous ulcer healing. Ninety patients were randomly assigned equally (30 per treatment group) to one of the abovementioned treatment groups. Patients received SOC therapy (multilayered compression bandages, nonadherent dressing and regular debridement) 3 times per week for 3 months or until the wound healed. Assessment of wound size, pain and lower leg edema occurred at baseline, 2 and 4 months. Statistically significant results were detected at 4 months with the wound area of the SOC group measuring $4.28 \mathrm{~cm}^{2}$, and the SOCHFU and SOC NCLFU group measuring 3.23 and $2.72 \mathrm{~cm}^{2}$, respectively. Edema and wound pain rating scores were also significantly different at 4 months with the SOC-NCLFU group demonstrating the most improvement.

The effects of SOC therapy versus HFU and NCLFU treatment in combination with SOC therapy, respectively, on 
venous ulcers was also examined by Beheshti et al ${ }^{56}$. Once again, 90 patients were assigned in equal numbers (30 per group) to each of the treatment groups (SOC, SOC-HFU and SOC-NCLFU). Ultrasound therapy in both groups was delivered 3 times per week until the wounds healed. Similar to the Olyaie et $\mathrm{l}^{55}$ study, the following variables were assessed at baseline, 2 and 4 months: time to complete healing, wound size, pain and edema. Complete wound healing was achieved at 8.13, 6.10 and 5.70 months, respectively, in the SOC, SOC-HFU and SOC-NCLFU groups. Again this small study showed that time to complete healing was statistically significant in the ultrasound treatment groups compared to the SOC therapy group. Wound pain and edema were also significantly decreased in the ultrasound-treated groups. Wound healing rates were not statistically different between the two ultrasound-treated groups. Additionally, no difference in recurrence rate was detected between any of the groups.

In 2014, Yao et al $^{27}$ studied the relationship between dose and duration in patients with nonhealing DFUs treated with NCLFU in a prospective, randomized clinical study. The correlation between wound healing and cytokine/proteinase/ growth factor profile was also examined. Twelve patients were randomly assigned to a SOC therapy group, a group receiving SOC-NCLFU once per week or a group receiving SOC-NCLFU three times per week. The group receiving SOC-NCLFU 3 times per week showed the greatest reduction in percentage of area reduction of the wound. SOC-NCLFU demonstrated an $86 \%$ reduction in wound area compared to 25 and $39 \%$, respectively, for the group receiving SOC therapy and NCLFU 1 time per week and the group receiving only SOC therapy. Examination of biological samples indicated a trend toward the reduction of proinflammatory cytokines (IL-6, IL-8, IL-1 $\beta$, TNF- $\alpha$ and GM-CSF) matrix metalloproteinases, vascular endothelial-derived growth factor (VEGF) and macrophage number with NCLFU treatment.

White et $\mathrm{al}^{57}$ in a single-site, evaluator-blinded randomized control trial SOC therapy delivered at least once weakly with NCLFU plus SOC therapy on change in wound area, quality of life (QoL) scores, pain scores and infection numbers. Wound area decreased by $47 \%$ in the SOC-NCLFU treatment group versus 39\% reduction in the SOC therapyonly treatment group. Infection number and change in QoL score were not significantly different. However, pain reduction was significantly different in the two groups. The SOCNCLFU treatment group exhibited a 14.4 point reduction in pain compared to a 5.3 point reduction in the SOC therapyonly group. Similarly, Samies and Gehling ${ }^{58}$ performed a retrospective chart review of 15 patients to determine the effects of NCLFU on pain levels. They found that mean pain scores in patients treated with NCLFU decreased from 8 at pretreatment to 1.7 at posttreatment. Patients had painful, nonhealing, lower extremity wounds that received treatment for 2-4 weeks. Early evidence indicates that NCLFU relieves pain associated with painful, chronic wounds.

\section{Conclusion}

Therapeutic ultrasound as a treatment modality or physical therapeutic device has been in existence for over 80 years. Evolving evidence points to a role for therapeutic ultrasound in promoting wound healing in both closed and open wound healing. The benefits of this technology for wound healing may be greater in acute injuries but hold promise for enhancing chronic wound healing. Newer technologies that take advantage of different treatment frequencies and delivery methods may more optimally deliver a therapeutic level of acoustic energy to both superficial and deep tissues. ${ }^{59}$ Optimizing specific frequencies to induce particular cellular and tissue changes may also produce more effective treatment paradigms. The next 80 years should be fascinating as this therapeutic agent evolves.

\section{Disclosure}

Dr Conner-Kerr previously received grant support from Advanced Medical Applications, Inc., Celleration, Inc. and Arobella, Inc. The authors report no other conflicts of interest in this work.

\section{References}

1. Wood RW, Loomis AL. The physical and biological effects of high frequency sound waves of great intensity. Philos Mag. 1927;4:417-436.

2. Speed CA. Therapeutic ultrasound in soft tissue lesions. Rheumatology. 2001;40(12):1331-1336.

3. Harvey EN. Biological aspects of ultrasonic waves: a general survey. Biol Bull. 1930;59:306-325.

4. Freundlich H, Sollner K, Rogowski F. Some biological effects of ultrasound. Klin Wochenschr. 1932;11:1512-1513.

5. Pohlman R, Richter R, Parrow E. Uber die ausbreitung und absorption des ultraschall im menschlichen gewebe und seine therapeutische wirkung an ischias und plexusneuralgie. Dtsch Med Wochenschr. $1939 ; 65: 251-254$

6. Wong RA, Schumann B, Townsend R, Phelps CA. A survey of therapeutic ultrasound use by physical therapists who are orthopaedic certified specialists. Phys Ther. 2007;87(8):986-994.

7. Wells PN. Physics and bioeffects. In: McGahan JP, Goldberg BB, editors. Diagnostic Ultrasound, A Logical Approach. Philadelphia, PA: Lppincott-Raven Publishers; 1998:1-19.

8. Ahmadi F, McLoughlin IV, Chauhan S. Bio-Effects and Safety of Low Intensity, Low Frequency Ultrasonic Exposure. Available from: http:// www.lintech.org/webpapers/bioeffects.pdf. Accessed November 12, 2016.

9. Draper DO, Schulthies S, Sorvisto P, Hautala AM. Temperature changes in deep muscles of humans during ice and ultrasound therapies: an in vivo study. J Orthop Sports Phys Ther. 1995;21(3):153-157. 
10. Draper DO, Castel JC, Castel D. Rate of temperature increase in human muscle during 1-MHz and 3-MHz continuous ultrasound. J Orthop Sports Phys Ther. 1995;22:142-150.

11. Ashton DF, Draper DO, Myrer JW. Temperature rise in human muscle during ultrasound treatments using flex-all as a coupling agent. J Athl Train. 1998;33(2):136-140.

12. Chan AK, Myrer JW, Measom G, Draper DO. Temperature changes in human patellar tendon in response to therapeutic ultrasound. $J$ Athl Train. 1998;33(2):130-135.

13. Pizzarello DJ, Wolsky A, Becker MH, Keegan AF. A new approach to testing the effect of ultrasound on tissue growth and differentiation. Oncology. 1975;31(3-4):226-232.

14. Ross P, Edmonds PD. Ultrasound induced protein synthesis as a result of membrane damage. J Ultrasound Med. 1983;2(suppl):47.

15. Webster DF, Pond JB, Dyson M, Harvey W. The role of cavitation in the in vitro stimulation of protein synthesis in human fibroblasts by ultrasound. Ultrasound Med Biol. 1978;4(4):343-351.

16. Anderson DW, Barrett JT. Depression of phagocytosis by ultrasound. Ultrasound Med Biol. 1981;7(3):267-273.

17. Pinamonti S, Gallenga PE, Mazzeo V. Effect of pulsed ultrasound on human erythrocytes in vitro. Ultrasound Med Biol. 1982;8(6):631-638.

18. Dyson M, Pond JB, Joseph J, Warwick R. The stimulation of tissue regeneration by means of ultrasound. Clin Sci. 1968;35(2): 273-285.

19. Lennart DJ. Nonthermal effects of therapeutic ultrasound: the frequency resonance hypothesis. J Athl Train. 2002;37(3):293-299.

20. Maxwell L, Collecutt T, Gledhill M, Sharma S, Edgar S, Gavin JB. The augmentation of leucocytes adhesion to endothelium by therapeutic ultrasound. Ultrasound Med Biol. 1994;20:383-390.

21. Mortimer AJ, Dyson M. The effect of therapeutic ultrasound on calcium uptake in fibroblasts. Ultrasound Med Biol. 1988;14(6):499-506.

22. Reher P, Doan N, Bradnock B, Meghji S, Harris M. Effect of ultrasound on the production of IL-8, basic FGF and VEGF. Cytokine. 1999;11(6):416-423.

23. Johns LD, Colloton PA, Neuenfeldt J. Effects of therapeutic ultrasound on T cell proliferation and IL-2 production [abstract]. J Athl Train. 1999;34(suppl):S24.

24. Doan N, Reher P, Meghji S, Harris M. In vitro effects of therapeutic ultrasound on cell proliferation, protein synthesis and cytokine production by human fibroblasts, osteoblasts and monocytes. J Oral Maxillofac Surg. 1999;57(4):409-419.

25. Webster D, Harvey W. The role of ultrasound-induced cavitation in the 'in vitro' stimulation of collagen synthesis in human fibroblasts. Ultrasonics. 1980;18(1):33-37.

26. Conner-Kerr T, Malpass G, Steele A, Howlett A. Effects of $35 \mathrm{kHz}$ low frequency ultrasound on human fibroblast migration. Ostomy Wound Manage. 2015;61(3):48-55.

27. Yao M, Hasturk H, Kantarci A, et al. A pilot study evaluating non-contact low-frequency ultrasound and underlying molecular mechanism on diabetic foot ulcers. Int Wound J. 2014;11(6):586-593.

28. Chinn NE, Clough AE, Clough PJ. Does therapeutic ultrasound have a clinical evidence base for treating soft tissue injuries? Int Musculoskeletal Med. 2010;32(4):178-181.

29. Shanks P, Curran M, Fletcher P, Thompson R. The effectiveness of therapeutic ultrasound for musculoskeletal conditions of the lower limb: a literature review. Foot (Edinb). 2010;20(4):133-139.

30. Robertson VJ, Baker KG. A review of therapeutic ultrasound: effectiveness studies. Phys Ther. 2001;81(7):1339-1350.

31. Van der Windt DA, Van der Heijden GJ, Van der Berg SG, Ter Riet G, De Winter AF, Bouter LM. Ultrasound therapy for musculoskeletal disorders: a systematic review. Pain. 1999;81(3):257-271.

32. Gam AN, Johannsen F. Ultrasound therapy in musculoskeletal disorders: a meta-analysis. Pain. 1995;63(1):85-91.

33. Ebrahim S, Mollon B, Bance S, et al. Low intensity pulsed ultrasonography therapy versus electrical stimulation for fracture healing: a systematic review and network meta-analysis. Can J Surg. 2014;57(3):E105-E118.
34. Busse JW, Kaur J, Mollon B, et al. Low intensity pulsed ultrasonography for fractures: systematic review of randomized controlled trials. BMJ. 2009;338:b351.

35. Conner-Kerr T, Sullivan PK, Koo J et al. Effects of pulsatile lavage with suction and mist ultrasound transport therapy on healing rates in acute porcine wounds: a histological study. In: 16th Annual Symposium on Advanced Wound Care \& Medical Research Forum on Wound Repair; May 2003; Las Vegas, Nevada.

36. Prather JL, Tummel EK, Patel AB, et al. Prospective randomized controlled trial comparing the effects of noncontact low-frequency ultrasound with standard of care in healing split-thickness donor sites. J Am Coll Surg. 2015;221(2):309-318.

37. Johannsen F, Gam AN, Karlsmark T. Ultrasound therapy in chronic leg ulceration: a meta-analysis. Wound Repair Regen. 1998;6(2):121-126.

38. Baba-Akbari SA, Flemming K, Cullum NA, Wollina U. Therapeutic ultrasound for pressure ulcers. Cochrane Database Syst Rev. 2006;(3):CD001275.

39. Nelson E, Jones J. Venous leg ulcers. BMJ Clin Evid. 2008;1902.

40. Reddy M, Gill SS, Kalkar SR, Wu W, Anderson PJ, Rochon PA. Treatment of pressure ulcers: a systematic review. JAMA. 2008;300(22): 2647-2662.

41. Ontario Ministry of Health and Long Term Care, Medical Advisory Secretariat (MAS). Management of chronic pressure ulcers: an evidencebased analysis. Ont Health Technol Assess Ser. 2009;9(3):1-203.

42. Cullum NA, AL-Kurdi D, Bell-Syer SE. Therapeutic ultrasound for venous ulcers. Cochrane Database Syst Rev. 2010;6:CD001180.

43. Driver VR, Yao M, Miller CJ. Noncontact low-frequency ultrasound therapy in the treatment of chronic wounds: a meta-analysis. Wound Repair Regen. 2011;19(4):475-480.

44. Hinchliffe RJ, Valk GD, Apelqvist J, et al. A systematic review of the effectiveness of interventions to enhance the healing of chronic ulcers of the foot in diabetes. Diabetes Metab Res Rev. 2008;24(suppl 1):S119-S144.

45. Gottrup F, Apelqvist J. Present and new techniques in the treatment of DFU: a critical review of evidence. Diabetes Metab Res Rev. 2012;28(suppl 1):64-71.

46. Kwan RL, Cheing GL, Vong SK, Lo SK. Electrophysical therapy for managing diabetic foot ulcers: a systematic review. Int Wound J. 2013;10(2):121-131.

47. Lundeberg T, Nordström F, Brodda-Jansen G, Eriksson SV, Kjartansson J, Samuelson UE. Pulsed ultrasound does not improve healing of venous ulcers. Scand J Rehabil Med. 1990;22(4):195-197.

48. Eriksson SV, Lundeberg T, Malm M. A placebo controlled trial of ultrasound therapy in chronic leg ulceration. Scand J Rehabil Med. 1991;23(4):211-213.

49. Peschen M, Weichenthal M, Schopf E, Vanscheidt W. Low intensity ultrasound treatment of chronic venous ulcers in an outpatient therapy. Acta Derm Venereol. 1997;77(4):311-314.

50. Ennis WJ, Foremann P, Mozen N, Massey J, Conner-Kerr T, Meneses P. Ultrasound therapy for recalcitrant diabetic foot ulcers: results of a randomized, double-blind, controlled, multicenter study. Ostomy Wound Manag. 2005;51(8):24-39.

51. Ennis WJ, Valdes W, Gainer M, Meneses P. Evaluation of clinical effectiveness of MIST ultrasound therapy for the healing of chronic wounds. Adv Skin Wound Care. 2006;19(8):437-446.

52. Kavros SJ, Miller JL, Hanna SW. Treatment of ischemic wounds with noncontact, low frequency ultrasound: The Mayo Clinic Experience, 2004-2006. Adv Skin Wound Care. 2007;20(4):221-226.

53. Kavros SJ, Schenck EC. Use of noncontact low frequency ultrasound therapy in chronic wounds: a retrospective analysis. Adv Skin Wound Care. 2008;21(9):416-423.

54. Polak A, Franek A, Blaszczak E, et al. A prospective, randomized, controlled clinical study to evaluate the efficacy of high-frequency ultrasound in the treatment of Stage II and Stage III pressure ulcers in geriatric patients. Ostomy Wound Manage. 2014;60(8):16-28.

55. Olyaie M, Rad FS, Elahifar MA, et al. High frequency and noncontact low-frequency ultrasound therapy for venous leg ulcer treatment: a randomized, controlled study. Ostomy Wound Manage. 2013;59(8):14-20. 
56. Beheshti A, Shafigh Y, Parsa H, Zangivand AA. Comparison of highfrequency and MIST ultrasound therapy for the healing of venous leg ulcers. Adv Clin Exp Med. 2014;23(6):969-975.

57. White J, Ivins N, Wilkes A, et al. Non-contact low-frequency ultrasound therapy compared with UK standard of care for venous leg ulcers: a single-centre, assessor-blinded, randomized controlled trial. Int Wound J. 2015;13(5):833-842.

58. Samies J, Gehling M. Acoustic pressure wound therapy for management of mixed partial- and full-thickness burns in a rural wound center. Ostomy Wound Manage. 2008;54(3):56-59.
59. Conner-Kerr T. Therapeutic ultrasound: finding the sweet spot for bioburden control and wound healing. J Nov Physiother. 2012;2:e109.

60. Dark Daily: Serving Clinical Labs \& Pathology Groups. American Medical Association's Study of Nation's 25 Largest Health Insurers Indicates that Biggest Companies Hold Dominant Market Share in Most Regional Markets. Available from: http:/www.darkdaily.com/ american-medical-associations-study-of-nations-25-largest-healthinsurers-indicates-that-biggest-companies-hold-dominant-marketshare-in-most-regional-markets-109\#axzz4YyCpn33a. Accessed October 12, 2016.

\section{Publish your work in this journal}

Chronic Wound Care Management and Research is an international, peer reviewed, open access, online journal publishing original research, reviews, editorials, and commentaries on the causes and management of chronic wounds and the major issues related to chronic wound management. Topics also include chronic wounds as comorbidities to other conditions, patient adherence to therapy, and the economic burden of chronic wounds. The manuscript management system is completely online and includes a very quick and fair peer review system, which is all easy to use. Visit http://www.dovepress.com/testimonials.php to read real quotes from published authors.

Submit your manuscript here: https://www.dovepress.com/chronic-wound-care-management-and-research-journal 